Vidyodaya J., of Sci., (1992). Vol 4, No. 1, pp: $117-129$

\title{
PRESENT STATUS OF THE SEINE FISHERY IN NEGOMBO LAGOON OF SRI LANKA.
}

\author{
Department of Zoology, \\ University of Kelaniya, \\ Kelaniya, Sri Lanka
}

M. J. S. Wijeyaratne and W. M. D. S. K. Perera

Received on : $24-09-1992$

Accepted on : 16-03-1993

\begin{abstract}
Studies on the seine fishery of Negombo Lagoon in the west coast of Sri Lanka $\left(7^{\circ} 10^{\prime} \mathrm{N}\right.$ and $\left.79^{\circ} 50^{\prime} \mathrm{E}\right)$ were carried out for a period of one year from May 1989 to April 1990. In the operation of this gear, 2 or 4 standard nets, each with a length of $32 \mathrm{~m}$ are used. Each net was made up of 4 or 5 vertically joined pieces of nets, with a stretched mesh size of $1.25 \mathrm{~cm} .3$ and 5 men are involved in 2 net and 4 net operations respectively. Total production from this gear was estimated to be around $36,000 \mathrm{~kg} /$ year. During the present study, 82 species of fish ranging in size from $2.5 \mathrm{~cm}$ to $130.0 \mathrm{~cm}$ were encountered together with 6 species of commercially important penaeid prawns. The catch and fishing effort were low from August to December. Catch per unit effort was high from February to May. Salinity and fish catch showed a significant positive correlation probably due to immigration of allochthonous marine organisms into the lagoon with increasing salinity. Fishing effort also showed a significant positive correlation with salinity. Significant difference between the catches of 4 net-piece and 5 net-piece nets was not observed $(P>0.05)$. Although the catch and catch per fisherman were significantly higher in 4 net operations than in 2 net operations $(P<0.05)$, significant difference in catch per net between the two operations was not observed $(P>0.05)$. 2 Net operations were observed to provide more employment opportunities and better distribution of income than 4 net operations. Threat of overexploitation of the resource was observed to be high in 4 net operations.
\end{abstract}

Key words : Negombo Lagoon, Seine fishery.

\section{Introduction}

The Negombo Lagoon on the West coast of Sri Lanka $\left(7^{\circ} 10^{\prime} \mathrm{N}\right.$ and $79^{\circ}$ $50^{\prime}$ E) with a surface area of 3100 ha has been identified as one of the most productive coastal environments in the tropics. Its annual fishery production has been estimated to be around $150 \mathrm{~kg} / \mathrm{ha}$ (Samarakoon and van Zon 1991). As in most other tropical waters, variety of fishing gear is operated in this 
lagoon. The contribution from seines to the total production of this brackishwater body has been estimated to be around $30 \%$ (Wijevaratne and Costa 1987 a). When compared with other types of gear operated in the lagoon which include cast nets, gill nets and brush parks, seining has been found to be the most labour intensive (Wijeyaratne and Costa 1987 b). In the management of small scale fisheries in developing countries, labour intensive gear play an important role in providing maximum social benefits since they mitigate the threat of unemployment at least to some extent (Kapetsky 1981, Panayotou 1982). Therefore, seines can be considered as an important type of gear in this highly productive ecosystem.

In the management of tropical fishery resources, catch and fishing effort statistics have become extremely important mainly because data on growth and mortality parameters of individual fish species are not available (Pauly 1984).

Present study was carried out to investigate on the catch and fishing effort of seines operated in the Negombo Lagoon as a prelude for the management of the fishery of this important gear in order to obtain the maximum social benefits.

\section{Materials and Methods}

\section{The gear}

The seine was $32 \mathrm{~m}$ in length. Height of the net varied with the number of net pieces used. Each net consistsed of 4 or 5 net pieces joined vertically with each other. Height of a net piece was approximately $1.25 \mathrm{~m}$. Mesh size of the net was $1.25 \mathrm{~cm}$ stretched mesh. To the top and the bottom of the net, 2 net units each with a height of $10 \mathrm{~cm}$ were attached. Mesh size of these units was $3 \mathrm{~cm}$ stretched mesh. To the float line, 40 to 65 rubber or wooden floats were attached. The bottom line generally did not contain sinkers.

\section{Operation procedure}

During the operation, two standard nets were attached to each other and were hauled in shoulder deep water for about 25 minutes. The catch was collected on to the out triggered craft. Generally the net was hauled about 15 times during the operation. Usually two men were involved in hauling and one man stayed in the craft manoeuvering it. Sometimes hauling was carried out using two nets, each consisting of 2 standard nets attached to each other. In such operations where 4 standard nets were used, 4 men hauled the net and one man manoeurered the craft. 


\section{Collection of data}

Total fish catch of seines was sampled once a week from May 1989 to April 1990 at the fish landing site at Katunayake (Fig. 1). On each sampling day, total fish catch of each craft was weighed to the nearest $10 \mathrm{~g}$. The fish were identified and the total lengths of the smallest and the largest specimens of each species were measured to the nearest $1 \mathrm{~mm}$. Information on the size of the net, number of nets used, number of fishermen involved in the operation, number of times the net was hauled and the time spent in fishing were also recorded.

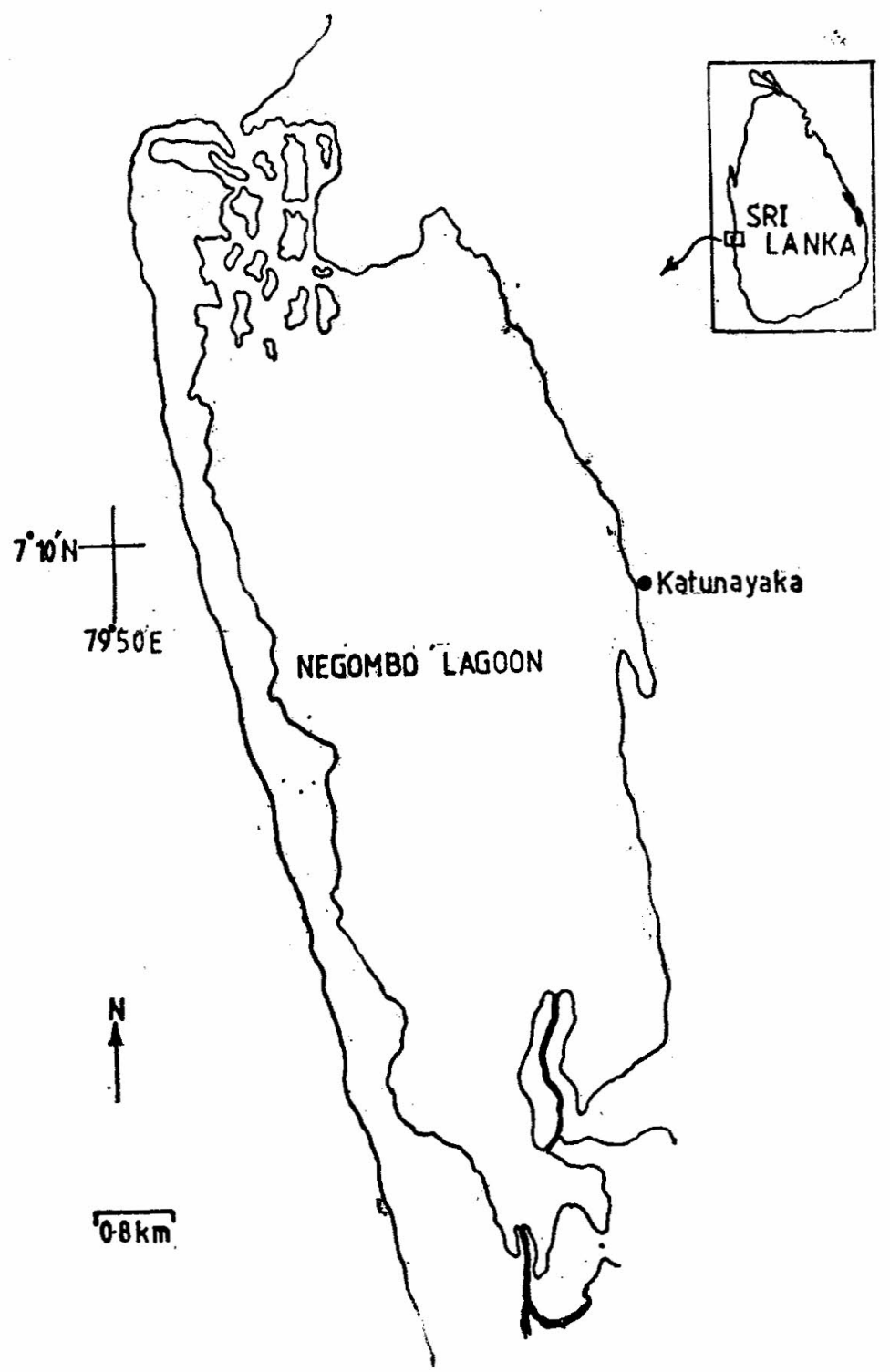

Fig. 1 Map of Negombo lagoon showing the sampling site. 
On each sampling day, salinity was measured by a salinity refractometer. Rainfall data for the study period were obtained from the Meteorological Department.

\section{Analysis of data}

In the present study, fishing effort was estimated in man-hours and number of net-pieces hauled. The catch and the catch per unit effort for the operations using 2 nets, each with 4 and 5 net-pieces and for those using 4 nets, each with 5 net-pieces were calculated and were statistically compared using one way Analysis of Variance (Zar 1974).

The relationship of catch, fishing effort and catch per unit effort with environmental paramenters such as rainfall and salinity were determined by the Pearson's correlation coefficient. Correlation coefficients between fishing effort, catch and catch per unit effort were also calculated.

\section{Results}

Eighty two fish species belonging to 41 families were recorded during the present study. They were categorized into 3 groups, viz, allochthonous freshwater, allochthonous marine and autochthonous species and are listed in Table I. 4 Allochthonous freshwater, 58 allochthonous marine and 20 autochthonous species were recorded. The smallest species caught was a $2.5 \mathrm{~cm}$ long specimen of Monodactylus argenteus. The largest specimen recorded was a $130.0 \mathrm{~cm}$ long sea perch (Lates calcarifer) which weighed $9.1 \mathrm{~kg}$.

Table I: Species of fish caught in the seines operated in Negombo Lagoon and their size range.

\section{A: Allocthonous fishes from freshwater.}

Family

1. Anguillidae

2. Cichlidae

3. Clariidae

4. Cyprinodontidae
Species

Anguilla bicolor

Etroplus maculatus

Clarias teysmanni

Panchax panchax blochii
Size-range (cm)

$31.5-63.0$

4.0-6.4

$15.1-34.5$

$3.1-4.6$ 
B. Autocthonous fishes from brackishwater

Family

1. Ambassidae

2. Bagridae

3. Cichlidae

4. Dorosomidae

5. Dussumieridae

6. Elopidae

7. Gobiidae

8. Megalopidae

9. Periophthalmidae

10. Tachysuridae
Species

Ambassis commersoni

Ambassis gymnocephalus

Macrones gulio

Etroplus suratensis

Nematalosa nasus

Ehirava fuviatilis

Elops machnata

Acentrogobius griseus

Glossogobius giuris

Mugilogobius valigouva

Megalops cyprinoides

Perhopithalmus koelreuteri

Aroides dussumieri

Neiuma thalassinus

Osteogeneiosus militaris

Pseudarius jella

Tachysurus caelatus

Tachysurus maculatus

Tachysurus subrostratus

Tachysurus venosus
Size-range (cm)

$5.0-9.6$

$5.6-9.7$

6.5-12.4

5.4-13.6

9.1-14.5

$4.0-4.2$

$7.0-18.8$

$5.2-7.8$

7.6-14.4

4.3-6.2

8.4-23.2

$5.4-8.5$

$5.6-10.2$

4.3-8.4

6.1-18.6

10.3-14.5

6.8-7.9

9.0-21.0

8.4-17.5

9.6-20.3

\section{C: Allocthonous fishes from the sea}

Family

1. Belonidae

2. Carangidae

3. Chanidae

4. Clupeidae

5. Cynoglossidae

6. Engraulidae

\section{Species}

Tylosurus leiurus

Alectis cilioris

Carangoides gymnostethoides

Caranx malabaricus

Caranx ignobilis

Caranx sunsun

Gnathanodon speciosus

Chanos chanos

Kowala coval

Macrura kelee

Sardinalla melanura

Sardinella albella

Cynoglossus lingua

Cynoglossus macrolepidotus

Anchoviella commersonii

Thrissina baelama

Thrissocles kammalensis
Size-range $(\mathrm{cm})$

34.3-41.2

$12.8-16.3$

18.3-20.4

$5.4-16.8$

$5.5-15.3$

$5.4-18.1$

16.6-18.4

$7.5-32.1$

4.8-5.0

8.0-13.4

11.5-14.0

9.6-12.0

13.0-20.6

12.6-21.8

$5.0-6.2$

4.5-6.0

$5.2-6.1$ 
7. Hemirhamphidae Hemirhamphus gaimardi

11.0-13.1

Hemirhamphus marginatus

$13.0-21.3$

8. Lactariidae

Lactarius lactarius

$11.0-16.4$

9. Latidae

Lates calcarifer

9.4-130.0

10. Leiognathidae

Leiognathus equulus

Leiognathus fasciatus

$6.0-9.6$

$6.4-9.8$

11. Lethrinidae

Lethrinus reticulatus

$11.8-15.4$

12. Lutianidae

Lutianus argentimaculatus

10.1-18.4

Lutianus fulviflamma

5.1-13.5

13. Mugilidae

Liza dussumieri

7.2-26.2

Liza macrolepis

$7.0-24.5$

Liza oligolepis

Liza parsia

$6.5-17.8$

Liza strongylocephalus

8.0-20.4

Liza tade

6.5-13.5

Liza waigiensis

$7.0-26.5$

Mugil cephalus

6.5-22.0

Valamugil buchanani

$7.8-40.0$

6.9-33.1

14. Monodactylidae

Monodactylus argenteus

2.5-6.7

15. Platycephalidae

Thysanophrys indicus

16.8-19.1

16. Plotosidae

Plotosus canius

17.2-32.3

17. Scatophagidae

Scatophagus argus

2.8-15.3

Otolithus rubra

19.2-22.2

Epinephelus fario

Epinephelus merra

5.4-11.6

5.7-14.9

Epinephelus tauvina

3.9-21.5

20. Siganidae

Siganus javus

3.2-7.8

Siganus oramin

4.3-10.1

Siganus vermiculatus

4.5-23.0

21. Sillaginidae

Sillago sihama

$11.8-14.2$

Brachirus orientalis

$14.0-17.8$

Acanthopagrus berda

5.4-10.5

23. Sparidae

Acanthopagrus latus

10.3-17.2

24. Sphyraenidae

Sphyraena jello

21.0-26.1

Chelonodon fluviatilis

3.7-9.4

Chelonodon patoca

3.5-8.7

26. Theraponidae

Autisthes puta

4.8-10.0

Therapon jarbua

$5.2-12.3$

Triacanthus biaculeatus

3.5-10.2

Triacanthus brevirostris

3.7-10.6

Trichiurus savala

$22.0-38.0$ 
Six species of prawns were also recorded in the catches. They were Penaeus indicus, $P$. monodon, $P$. monocros, $P$. semisulcatus, Matapenaeus dobsoni and Macrobrachium rosenbergii. Of these, $M$. dobsoni was the most abundant. $M$. rosenbergii was very rarely caught. Crab species such as Scylla serrata and Portunus pelagicus were also caught in small numbers.

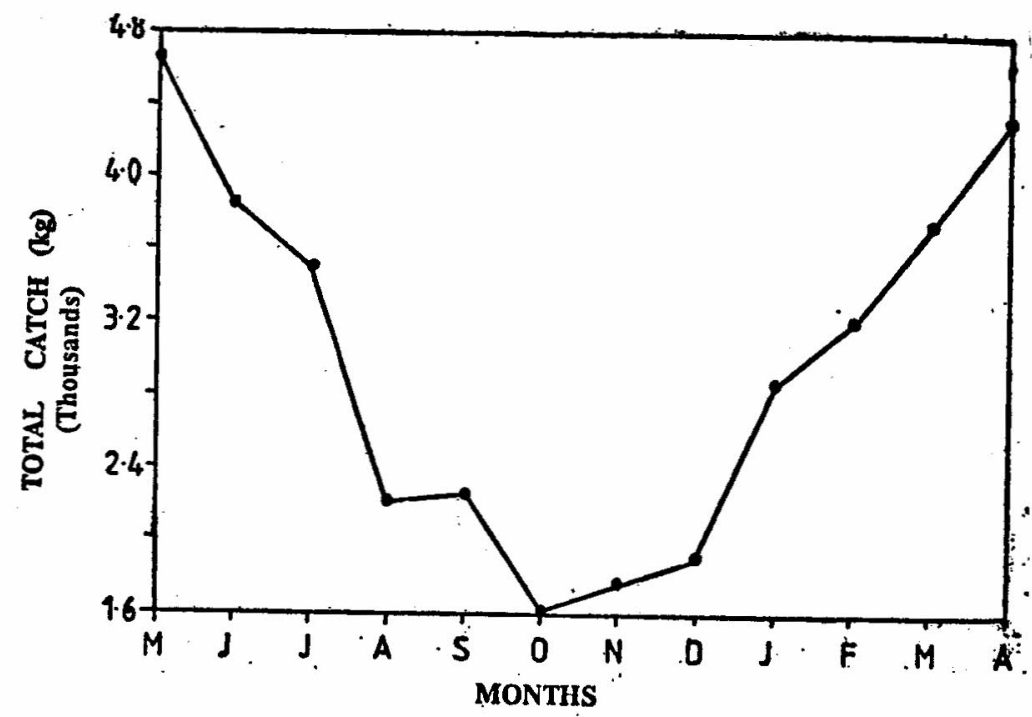

Fig. 2 Seasonal variation of monthly fish catches of the seines operated in Negombo Lagoon.

Seasonal variation pattern of the total fish catch is shown in Fig. 2. The highest catch of $4650 \mathrm{~kg}$ was recorded in May and the lowest catch of $1620 \mathrm{~kg}$ was obtained in October. A gradual decrease of the catch from May to October was evident. The catch increased from October to May.

The total yield from the seine fishery was estimated to be $35931.8 \mathrm{~kg} /$ year.

Seasonal variation pattern of the fishing effort is shown in Fig. 3. The fishing effort was found to be higher from Marcl to July than in other months. The annual fishing effort was estimated to be around 51000 man-hours or 380,000 net-piece hauls. 


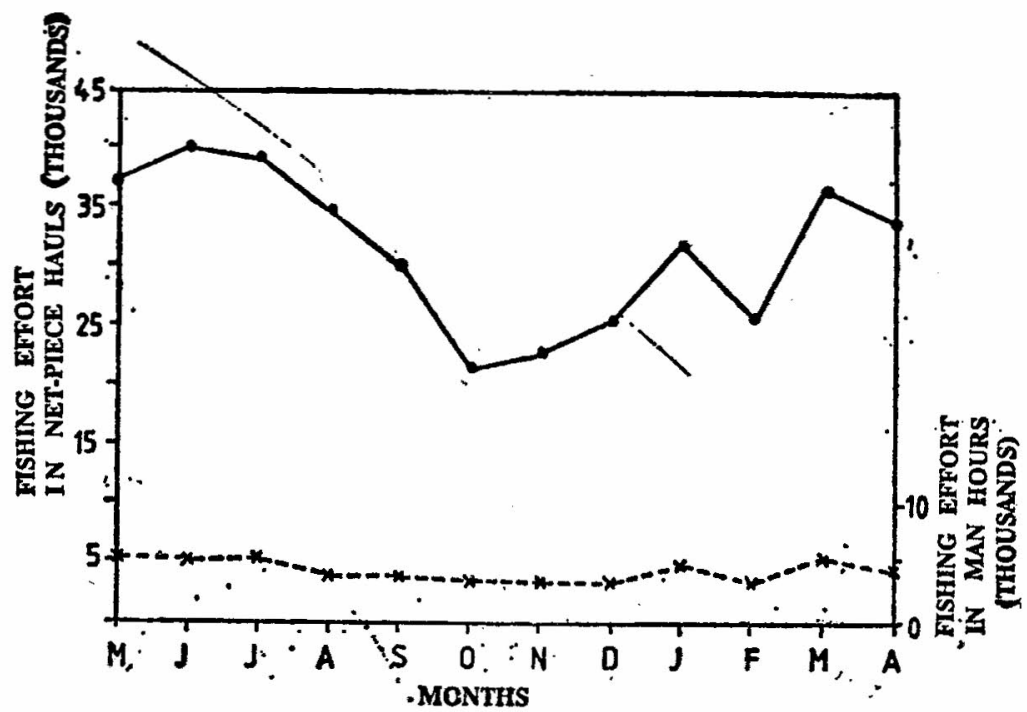

Fig. 3 Seasonal variation of the mean daily fishing effort of seines operated in Negombo Lagoon.

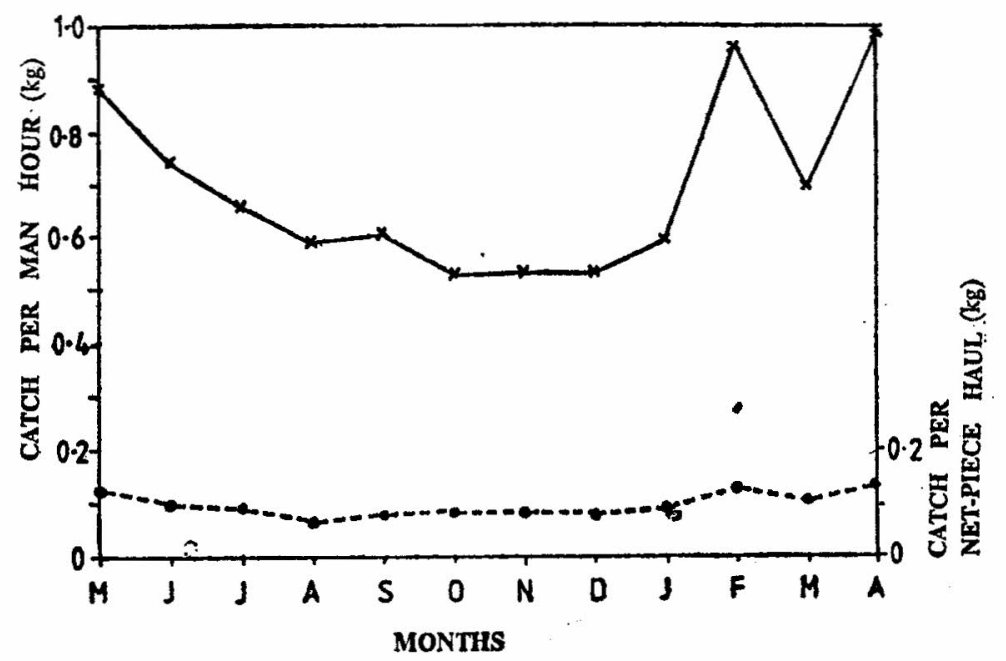

Fig. 4 Seasonal variation of the mean daily catch per unit effort of seines operated in Negombo lagoon.

Seasonal variation of the catch per unit effort (CPUE) is shown in Fig 4. CPUE was observed to be higher from February to May than in other months. 
During the study period, the maximum rainfall of $600 \mathrm{~mm}$ was recorded in October. In January and July no rains were experienced. The values for salinity ranged from $0.2 \%$ observed in October to $3.2 \%$ observed in January.

Simple linear correlation coefficients between environmental parameters and catch-effort statistics are given in Table II. Although catch, fishing effort and CPUE were negatively correlated with rainfall, the correlation coefficients were statistically not significant $(P>0.05)$. The catch and fishing effort showed a significant positive correlation with salinity $(P<0.05)$. The correlation coefficients between CPUE and the parameters such as salinity and fishing effort were found to be statistically not significant $(P>0.05)$

Table Ir: Simple linear correlation coefficients between environmental parameters and catch-effort statistics of seines operated in Negombo lagoon.

$\begin{array}{ll}\text { C } & =\text { Total catch } \\ \text { CPUE1 } & =\text { Catch per net-piece haul } \\ \text { CPUE2 } & =\text { Catch per man-hour } \\ \text { E1 } & =\text { Fishing effort in net-piece hauls } \\ \text { E2 } & =\text { Fishing effort in man-hours }\end{array}$

PAIR OF PARAMETERS

CORRELATION

$\mathbf{P}$ COEFFICIENT

$\begin{array}{lllll}\text { Rainfall } & * & \text { C } & -0.45 & >0.05 \\ & * & \text { CPUE1 } & -0.27 & >0.05 \\ & * & \text { CPUE2 } & -0.25 & >0.05 \\ & * & \text { E 1 } & -0.48 & >0.05 \\ & * & \text { E 2 } & -0.49 & >0.05 \\ & & & & <0.05 \\ \text { Salinity } & * & \text { C } & +0.67 & >0.05 \\ & * & \text { CPUE1 } & +0.48 & >0.05 \\ & * & \text { CPUE2 } & +0.50 & <0.05 \\ & * & \text { E 1 } & +0.65 & <0.05 \\ & * & \text { E 2 } & +0.62 & <0.05 \\ & & & & <0.05 \\ \text { C } & * & \text { E 1 } & +0.77 & >0.05 \\ & * & \text { E 2 } & +0.79 & >0.05 \\ \text { CPUE1 } & * & \text { E 1 } & -0.29 & \end{array}$


Table III: Catch and fishing effort statistics of the seines of different sizes. (Standard deviations are given within brackets).

2 net operation 2 net operation 4 net operation (Each net with (Each net with (Each net with 4 net-pieces) 5 net-pieces) 5 net-pieces)

Mean catch per day $(\mathrm{kg})$ $12.42 \quad(5.23) \quad 12.05 \quad(2.44)$ 32.84 (11.26)

Mean number of hauls per day $13.20 \quad(1.82) \quad 13.16 \quad(1.17) \quad 14.69 \quad(3.32)$

Mean catch per net per day $(\mathrm{kg})$ $\begin{array}{llllll}6.21 & (2.61) & 6.03 & (1.22) & 8.21 & (2.82)\end{array}$

Mean catch per net per haul $(\mathrm{kg})$

$0.47(0.19)$ $0.46(0.11)$ $0.59 \quad(0.25)$

No of fishermen involved in operation

Mean daily catch per fisherman $(\mathrm{kg})$

Catch and effort statistics for the seines of different sizes are summarized in Table III. Results of the Analyses of Variances carried out for these data are given in Table IV. Catch, catch per net and catch per net per haul were found to be not significantly different in the nets with 4 net-pieces and 5 net-pieces $(P>0.05)$. However, when 4 nets are used in the operation, total catch and catch per fisherman were found to be significantly higher than those in 2 net operations $(P<0.05)$. Catch per net, number of hauls per day and catch per net per haul were found to be not significantly different between 2 net operations and 4 net operations ( $\mathrm{P} 0>.05)$. 
Table IV: Summary of the results of analysis of variance performed on daily catch and effort data of the seines of different sizes.

$\begin{array}{lllllll}\text { SOURCE } & \text { DF } & \text { SS } & \text { MS } & F & P\end{array}$

Mean catch

$\begin{array}{lrrrrr}\text { Factor } & 2 & 1986.5 & 993.3 & 25.97 & 0.000 \\ \text { Error } & 24 & 917.9 & 38.2 & & \\ \text { Total } & 26 & 2904.4 & & & \end{array}$

Mean catch per net

$\begin{array}{lrrrrr}\text { Factor } & 2 & 20.82 & 10.41 & 2.26 & 0.126 \\ \text { Error } & 24 & 110.58 & 4.61 & & \\ \text { Total } & 26 & 131.40 & & & \end{array}$

Catch per fisherman

$\begin{array}{lrrrrr}\text { Factor } & 2 & 29.18 & 14.59 & 6.15 & 0.007 \\ \text { Error } & 24 & 56.90 & 2.37 & & \\ \text { Total } & 26 & 86.70 & & & \end{array}$

Number of hauls

$\begin{array}{lrrrrr}\text { Factor } & 2 & 10.61 & 5.31 & 1.32 & 0.287 \\ \text { Error } & 24 & 96.78 & 4.03 & & \\ \text { Total } & 26 & 107.39 & & & \end{array}$

Catch per net per haul

$\begin{array}{lrrrrr}\text { Factor } & 2 & 0.0691 & 0.0345 & 1.15 & 0.333 \\ \text { Error } & 24 & 0.7208 & 0.0300 & & \\ \text { Total } & 26 & 0.7899 & & & \end{array}$

\section{Discussion}

Total number of fish species observed in the present study is higher than the number that has been recorded earlier from this estuary by De Silva and Silva (1979). Nine families, namely, Bagridae, Clariidae, Cynoglossidae, Dorosomidae, Elopidae, Hemirhamphidae, Monodactylidae, Platycephalidae, and Sillaginidae were observed in this study in addition to those recorded by De Silva and Silva (1979). However, 6 families namely Acanthuroidaee, Atherinidae, Eleotridae, Lagocephalidae, Mullidae and Plectorhychidae, which have been recorded by De Silva and Silva (1979) were not encountred in the present study. This may possibly has resulted due to the differences in the types of gear sampled in the two studies. De Silva and Silva (1979) obtained their samples from brush parks while the present study dealt with seines. Therefore, it is possible that differences in the spatial distribution and preference to a particular habitat of different species have contributed to the variations in the species composition encountered in the two studies. 
Three families, viz, Lethrinidae, Monodactylidae and Platycephalidae which were observed in the present study have not been recorded by Pillai (1965) who has carried out an extensive study on brackishwater fish and fisheries of Sri Lanka.

Of the 82 fish species recorded, Chelodon patoca and C. fluviatilis are not consumed because their flesh is considered to be poisonous. Economically most valuable food fishes were Lates calcarifer, Siganus spp., Liza spp., Mugil cephalus, Chanos chanos and Etroplus suratensis. Small individuals of Scatophagus argus, Monodactylus argenteus, Lates calcurifer and Epinephelus spp. are important as ornamental fish and aquaculture seed. When caught, they are kept alive to be sold separately.

Total fish catch of seines estimated in the present study is higher than that recorded in 1980-82 by Wijeyaratne and Costa (1987 a). However, the total fishing effort in man-hours estimated in the present study is smaller than the value recorded in 1980-82. The reason for high catches observed in the present study may possibly be attributed to the environmental conditions. The 1980-82 period was characterized with unusually dry weather conditions. Low productivity may have resulted due to low rainfall which has minimized the surface run-off and river discharges into the lagoon which bring in large amount of nutrients responsible for high productivity.

When the seasonal variation pattern of total fish catch was considered, during 1980-82 low catches from this gear have been recorded from November to February (Wijeyaratne and Costa 1987 a). In the present study, low catches were observed from August to December. However, in 1980-82 and in the present study, high catches were recorded from April to July.

In 1980-82, total fishing effort of this gear was observed to be high from February to May and in October (Wijeyaratne and Costa 1987 b). In the present study, fishing effort was observed to be low from April to December and in February. However, in 1980-82 period and in the present study high values for fishing effort have been recorded in April and May. These results indicate that the seasonal variation patterns of catch and fishing effort of a particular fishery may vary from time to time.

High values for CPUE observed from February to May indicate that there is a possibility of increasing the fishing effort during this period. However, since the total catch and CPUE are low from August to December, it is desirable to maintain the fishing effort at a minimum level during these months.

The main reason for the significant positive correlation observed between fish catch and salinity is the increased migration of allochthonous marine species into the lagoon during the period of high salinities (McDowall, 1988). 
When salinity is high, fishermen, through experience know that there is high amount of fish in the lagoon and much fishing effort is exerted during these periods. Thus, a significant positive correlation results between the fishing effort and salinity.

Statistical analysis indicates that there is no significant difference in the total catch per net between 4 net-piece nets and 5 net-piece nets. Therefore, use of nets with 5 net-pieces instead of 4 , will only increase the cost of preparation of the net.

Similarly, there is no significant difference in the catch per net between the 4 net and 2 net operations. However, the total catch and catch per haul are significantly higher in 4 net operations than in 2 net operations as expected. Statistical analysis also indicates that the catch per fisherman is significantly higher in 4 net operations than in 2 net operations.

In the developing countries, management of fisheries should be aimed also at generating more employment and distribution of income (Panayotou 1982). Results of the present study indicate that 2 net operations provide more employment opportunities and a better distribution of income than 4 net operations. In addition, due to higher fish catches, threat of over exploitation of the resources is also higher in 4 net operations than in 2 net operations.

\section{References}

De Silva, S.S. and Silva, E.I.L., 1979. Biology of young grey mullet Mugil cephalus L Popu. lation of a coastal lagoon in Sri Lanka. J. Fish Biol., 15: 9-20.

Kapetsky J.M., 1981. Some Considerations for the Management of Coastal Lagoon and Estuarine Fisheries. FAO. Fish. Tech. Pap., 218: 47pp.

McDowall, R.M., 1988. Diadromy in Fishes. Migration Between Fresh Water and Marine Envircnment. Croom Helm, Lendon. 308pp.

Panayotou, T., 1982. Management Concept for Small Scale Fisheries: Economic and Social Aspects. FAO Fish. Tech.pap., 228 53pp.

Pauly, D., 1984. Fish Population Dynamics in Tropical Waters. A Manual for Use With Programmable Calculators. ICLARM, Manila, Philippines. $325 \mathrm{pp}$.

Pillai, T.G., 1965. Brackishwater fishery resources of Ceylon. Bull. Fish. Res. Stn Ceylon. 18: $75-86$.

Samarakoon, J.I. and Hans van Zon, 1991. Environmental Profile of Muthurajawela and, Negombo Lagoon. Greater Colombo Eccnomic Commission, Sri Lanka and Euroconsult, The Netherlands. 173pp.

Wijeyaratne, M.J.S. and Costa, H.H., 1987a. On the management of the fin fish fishery of Negombo lagoon, Sri Lanka. Indian J. Fish., 34(1): 41-47.

Wijeyaratne, M.J.S. and Costa, H.H., 1987b. Fishery, seasonal abundance and mortality of grey mullets (Pisces: Mugilidae) in Negombo lagoon, Sri Lanka. J. Appi. Ichthyol., 3(3): 115-118

Zar, J.H., 1974. Biostatistical Analysis. Prentice-Hall Inc., Englewood, Clifts, N. J. USA., $718 \mathrm{pp}$. 